\title{
Preliminary Studies of the Water Quality in the Reservoir Wielkopolska at Different Times of Operation on the Basis of Selected Indicators
}

\author{
Natalia Walczak ${ }^{1 *}$, Zbigniew Walczak ${ }^{2}$ \\ 1 Department of Hydraulic and Sanitary Engineering, Poznan University of Life Sciences, 60-637 Poznań, \\ Poland \\ 2 Department of Construction and Geoengineering, Poznan University of Life Sciences, 60-637 Poznań, Poland \\ *Corresponding author's e-mail: natalia.walczak@up.poznan.pl
}

\begin{abstract}
For the purposes of research and this resultant publication, the water quality was tested in three reservoirs differing in operating times. It was assumed that the study period covering autumn, spring and early summer was the period with the most visible changes in the concentrations of pollutants. The samples taken from the reservoirs were analysed by determining biological oxygen demand $\left(\mathrm{BOD}_{5}\right)$, ammonia concentration $\left(\mathrm{NH}_{4}\right)$, phosphate concentration $\left(\mathrm{PO}_{4}\right)$ and total suspended solids. The use of indicators allowed for assessing the quality of water in these reservoirs and comparing it in terms of different periods of their operation. It was also observed that the water flowing into the Roszków and Jeżewo reservoirs (two oldest reservoirs) was of worse quality than the outgoing water. In the case of the newest reservoir, the water quality at the outflow deteriorated in relation to all indicators.
\end{abstract}

Keywords: water quality, reservoirs, nitrogen, phosphorus, $\mathrm{BOD}_{5}$, total suspended solids

\section{INTRODUCTION}

Water is one of the main elements necessary to sustain life of all organisms in the ecosystem. Water pollutants can be divided into: natural and artificial. Natural pollutants include solutions of salts (admixtures), gases, organic substances or microorganisms (Budkowska Katarzyna, 2019). The greatest amount of these pollutants is found in seawater and groundwater, and the smallest in rainwater (Morawiec et al., 2019). The pollution of anthropogenic origin result from the direct and indirect human activity and is most often associated with the runoff from the agricultural areas or the discharge of municipal or industrial wastewater.

The inflow of nitrogen and phosphorus compounds is particularly dangerous for the aquatic environment (Kanclerz et al., 2010; Kowalik et al., 2014; Sojka, 2009).

The factors that affect the loads of biogenic compounds in surface waters to are: catchment area management (Friedl and Wüest, 2002), size and relief of the area, type of vegetation and degree of vegetation coverage, population density, sanitary and industrial infrastructure, fertilization level and method, livestock and others (Giercuszkiewicz-Bajtlik, 1990; Ilnicki, 2002). In general, reservoirs with dams are ecosystems that accumulate biogenic substances and various pollutants (Bayram et al., 2014; Fučík et al., 2008; Orzepowski et al., 2014; Wiatkowski et al., 2016; Wiatkowski and Paul, 2009). Furthermore, the use of catchment areas for agriculture and other business activities affects the degree of water pollution (Szczykowska and Siemieniuk, 2011).

Nitrogen and phosphorus compounds end up in waters, i.e. from area sources, and are assigned to agricultural activities (Policht-Latawiec et al., 2014; Pulikowski et al., 2012; Smoroń and Twar$\mathrm{dy}, 2004)$. The pollution originating from agricultural areas is primarily characterised by a high content of nutrients from domestic and household sewage discharges, and from fertilizers (mainly 
nitrogen, phosphorus and potassium compounds) (Bieroński, 2014). Their occurrence in reservoirs should be linked to rainwater, which as a result of surface runoff wash out pollution from catchment areas (Gromiec and Dojlido, 2006). A realistic assessment of the number of nitrogen compounds discharged from agricultural catchments is one of the basic elements of water protection systems in most countries (Gallo et al., 2015; Grizzetti et al., 2015), and it takes on a very important meaning when reservoirs are particularly at risk of eutrophication (Wilk et al., 2019).

The quality of underground waters supplying reservoirs depends, among others, on the type of soil and geological substratum as well as the composition of vegetation cover, relief or even the exposition of slopes (Malek et al., 2019). The immediate vicinity of woodland to catchment areas also affects the chemical quality of the water transported to reservoirs.

The human economic activity significantly contributes to the degradation of water and accelerates the process of eutrophication. The water from agricultural catchments and reservoirs located in cities is particularly susceptible to fast degradation (Grochowska et al., 2019).

The Polish water resources are small compared to the total European water resources. The average is approx. $1800 \mathrm{~m}^{3}$ of water per person, whereas in other areas of Europe, the number reaches approx. $5000 \mathrm{~m}^{3}$ of water per person. This low water content in Poland is caused by adverse hydrological and climatic conditions: Therefore, the quality of water stored in reservoirs is all the more important. The classification of reservoirs in terms of the water quality in Poland is regulated by the Regulation of the Minister of Maritime Economy and Inland Navigation of October 11,2019 , on the classification of ecological status, ecological potential and chemical status of surface water bodies and the Water Law Act of July 20, 2017. With the accession of Poland to the European Union in 2004, Directive 2000/60/EC of the European Parliament and of the Council of October 23, 2000 came into force, establishing the framework for European action in the field of water policy. The overall objective of the Water Framework Directive is to eliminate the substances that are hazardous to the aquatic environment, and thus to obtain the concentrations of substances as close as possible to those naturally occurring in the environment. The deadline for achieving a good surface water status in Poland has been prolonged from 2015 to 2027 , due to subsequent accession to the European Union and previous major negligence in the protection of water resources.

In order to assign a reservoir to an appropriate water quality class, certain parameters must be met, grouped by the legislator into main categories: biological, hydromorphological and physicochemical. Each category is assigned with appropriate indicators for individual surface water bodies (natural watercourses, lakes or other water bodies of natural origin along with transitional and coastal waters). The ecological potential for individual water bodies refers to surface water bodies artificially and significantly modified. By analysing the results of the status classification and ecological potential, the status of individual water bodies is assessed as good or bad.

The aim of the study was to assess the water quality of three retention reservoirs differing in their operating time. All reservoirs (Roszków, Jeżewo and Jaraczewo) are located in the region of Wielkopolska, which has the largest water deficit in Poland (Juszczak and Kędziora, 2004). They were created to prevent floods and collect water for the agricultural purposes i.e. subsoil irrigation of grassland.

\section{MATERIALS AND METHODOLOGY}

For the purposes of this study, the water samples collected from three reservoirs located in the region of Wielkopolska, which differ in construction periods and thus their operating times (Fig. 1), were analysed.

The Roszków Reservoir with an average depth of $2.9 \mathrm{~m}$ was created in 1997 by partitioning and damming the Lubieszki River with an earth dam. The river valley was filled with water over a length of approx. 800 meters, creating a reservoir. The reservoir has the following parameters: depth at the dam $-7.2 \mathrm{~m}$; flood area 32.4 ha, total volume $-981000 \mathrm{~m}^{3}$. The source of the Lubieszka River is located near the town of Sapieżyn (Krotoszyński administrative district) at approx. $35 \mathrm{~km}$ course of the river, and it flows to the left to the Lutnia river which is a left-bank tributary of the Warta river.

The river area is monitored by the Regional Inspectorate for Environmental Protection in Poznan, which, based on the conducted tests (in 2017), concluded that the state of physicochemical 


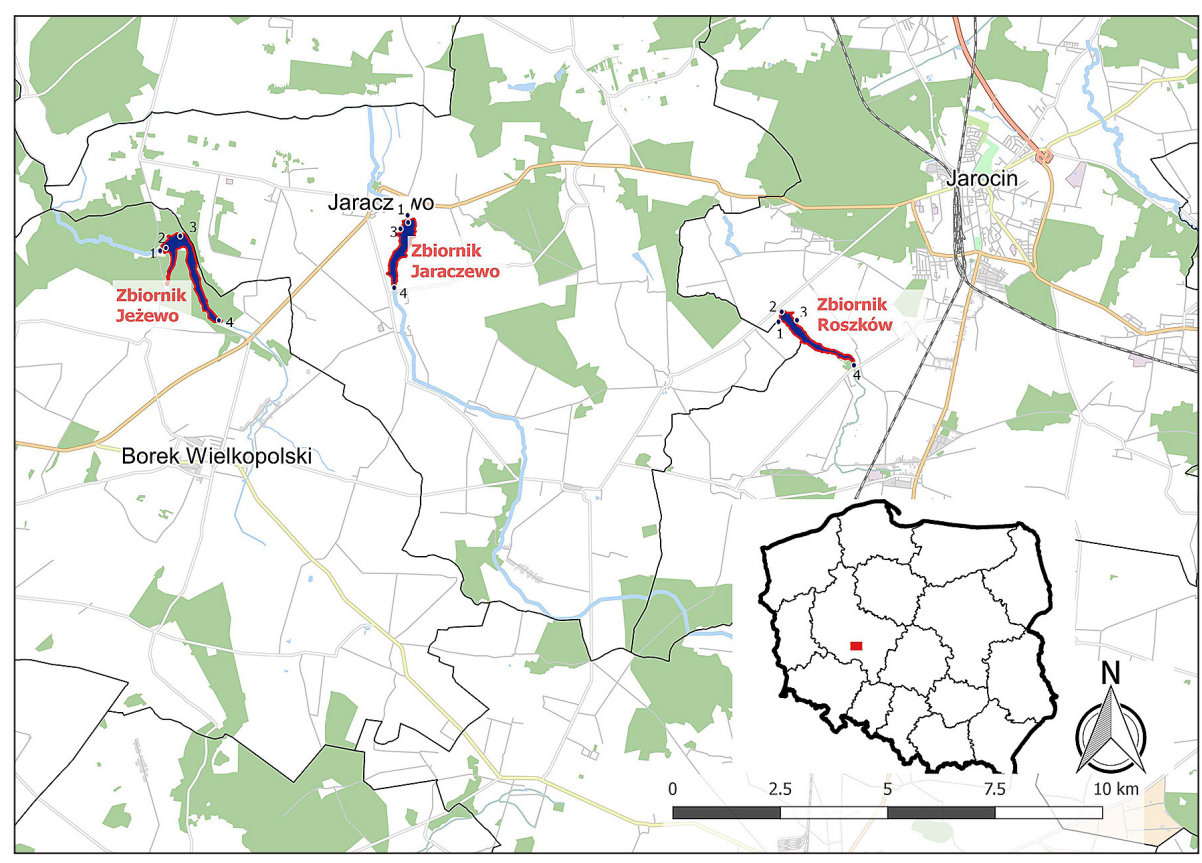

Fig. 1. Location of three reservoirs

parameters is below good, and the state of flowing individual water bodies is poor. Due to the construction of the Roszków reservoir, the section of the Lubieszki River was significantly changed. The primary objective of the construction was to collect water for agricultural purposes while preventing floods. In addition, by building the reservoir, it has been possible to arrange areas for recreation and fishing. The Roszków reservoir is located mainly on arable land, which is crucial in assessing the water quality. The agricultural use requires the use of mineral and natural fertilizers, which can remain in bottom sediments, often for a long time.

The second analysed reservoir was the Jeżewo reservoir, administratively belonging to the Borek Wielkopolski commune, Gostyń administrative district, Wielkopolska region, constructed in 2000-2004. The reservoir is located in the Pogona river valley. It is a 15 -year lowland reservoir of a valley type shaped similarly to the inverted letter $\mathrm{S}$. The reservoir is $2.2 \mathrm{~km}$ long and covers the area of 75.35 ha (Przybyła, Sosiński and Pochylska, 2009). The main function of the reservoir is to collect water to protect the valley of the Kościański Obra Canal against flooding and for subsoil irrigation of grassland (approx. 520 ha). The Jeżewo water reservoir is also used for recreational and fishing purposes. Through the construction of the reservoir, the biodiversity of flora and fauna of the catchment area has been enriched and beneficial microclimate changes have been observed in its immediate vicinity (Czerniak and Pelc, 2006). The catchment area of the reservoir is mainly used for forestry and agriculture. Woodland areas have a very beneficial effect on regulating the water cycle, and therefore the construction of a reservoir in such a place substantially improves the overall water balance (Mioduszewski, 2008). However, based on the monitoring carried out by the Regional Inspectorate for Environmental Protection in Poznan, it was found that the potential of physicochemical parameters of the Pogona River in 2016 was below good.

The third reservoir examined was the Jaraczewo reservoir located in the region of Wielkopolska, Jarociński administrative district in the Jaraczewo commune. It is the newest reservoir (5 years of operating time), which was established in 2014 by partitioning the Obra River. The front dam is located at $\mathrm{km} 3+258$ of the watercourse (Operat wodny Jaraczewo, 2010) for the purpose of storing water for agricultural purposes and flood protection. The reservoir also provides space for recreation and fishing. The Jaraczewo reservoir parameters are as follows: reservoir capacity $-798250 \mathrm{~m}^{3}$, reservoir area $-37.40 \mathrm{ha}$, average depth $-2.13 \mathrm{~m}$, reservoir length $-2.1 \mathrm{~km}$. The catchment area of the Jaraczewo reservoir is located mainly on grounds composed of clays and dusts and a small share of sands and solid rocks. Due to the economic factors and the fact that the reservoir is quite new, the water quality monitoring is not carried out. 
The water samples were collected from the reservoirs from October to December 2018 and from March to May 2019 in monthly cycles. Four samples were taken from each of the tested reservoirs: at the bottom outlet (1), at the water outflow from the reservoir, at the overflow tower (2), at a selected place at the waterside (3), at the water inlet to the reservoir (4). The samples for the water quality analyses were taken from approx. $20-50 \mathrm{~cm}$ below the water table using a $500 \mathrm{ml}$ bucket, fixed on a cord. The first water sampling was used for rinsing the bucket and sample bottles. Once the bucket was completely filled with the tested water, the water was mixed with a glass rod, and then poured into the previously prepared bottles, according to the guidelines by Regional Inspectorate for Environmental Protection in Warsaw, 2014. The collected water samples were protected from the sun and stored in the fridge until laboratory analysis. The collected water samples were used for determining the parameters enabling the assessment of the water quality. The laboratory analyses of the water samples were carried out in the laboratory of the Department of Hydraulic and Sanitary Engineering, University of Life Sciences in Poznań. The following indicators were determined: biochemical oxygen demand over 5 days $\left(\mathrm{BOD}_{5}\right)$, The selection of indicators took into account: physical state, including thermal (total suspended solids), oxygen conditions and organic pollution $\left(\mathrm{BOD}_{5}\right)$ and biogenic conditions $\left(\mathrm{NH}_{4}\right.$ and $\left.\mathrm{PO}_{4}\right)$

Biochemical oxygen demand is a measure of the oxygen removed from the system over time as a result of biological activity related to the decomposition of organic substances by bacteria. The most intensive processes occur in the first 5 days $\left(\mathrm{BOD}_{5}\right)$, which usually corresponds to about 68 to $70 \%$ of the total biochemical demand oxygen. For these reasons, $\mathrm{BOD}_{5}$ was adopted as an indicator parameter. The concentration of ammonia as an indicator of water quality resulted from the presence of a specific form of ammonia in water, which depends on the $\mathrm{pH}$ and temperature of the water. If the water $\mathrm{pH}$ is high, ammonia will be present as a gas. Conversely, i.e. with a low $\mathrm{pH}$, ammonia will appear in a soluble form. In natural waters, the most common form is ammonia in its soluble form $(99.8 \%)$. The rationale for choosing ammonia as an indicator of water pollution is that it can already be ascertained organoleptically, as the presence of ammonia in water changes its taste and smell. Ammoniacal nitrogen in surface waters comes from the biochemical breakdown of plant and animal organic matter. Its anthropogenic source involves discharges of municipal or industrial wastewater (e.g. from coking plants). Determination of phosphorus in surface waters is of great importance, because phosphates are one of the basic nutrients, contributing to the growth of algae, just like nitrogen compounds. Phosphorus in natural waters may come from the decomposition of plant or animal organic compounds, from fields fertilized with phosphorus fertilizers and from pollution with industrial sewage. The process takes place particularly intensively in surface waters, where microorganisms assimilate phosphates, and then, dying, sink to the bottom, where in turn mineralization takes place.

The laboratory analyses undertaken to determine the concentration of ammonium were carried out by spectrophotometry and the investigations aimed to determine the concentration of phosphate were performed using the ammonium nitrogen test $0.010-3.00 \mathrm{mg} \cdot \mathrm{dm}^{-3} \mathrm{~N}-\mathrm{NH}_{4}$ and the Merck phosphate test. The test for the content of total suspended solids was carried out by draining the test water sample through a smooth filter paper, then subjected it to a drying process at $105^{\circ} \mathrm{C}$.

The results allowed for assessing the water quality according of the Minister of the Environment of October 9, 2019 on the forms and methods of monitoring surface water bodies and groundwater bodies.

\section{RESULTS AND DISCUSSION}

During the entire six-month research period, 24 samples were collected from each reservoir. Each sample was analysed in terms of the physical and chemical characteristics, which allowed for assessing the class of water quality. Table 1 summarizes the measured indicators of water quality in individual reservoirs depending on sampling points.

The Roszków reservoir has the longest operating time among the analysed reservoirs. The water quality of the Lubieszka river flowing through the reservoir is not satisfactory, as indicated by the exceeded limit values of indicators for $\mathrm{BOD}_{5}$ in 12 out of 24 samples, and for total suspended solids in all tested water samples. The analyses of the ammonium nitrogen and phosphate phosphorus $(\mathrm{V})$ contents in the water samples showed the occurrence of phosphate pollution in as many 
Table 1. List of measured water quality indicators for individual reservoirs

\begin{tabular}{|c|c|c|c|c|}
\hline Index & \multicolumn{4}{|c|}{ Place of measurement } \\
\hline \multirow[b]{2}{*}[\mathrm{mg}\cdot\mathrm{dm}^{-3}]{} & 1 & 2 & 3 & 4 \\
\hline & \multicolumn{4}{|c|}{$\begin{array}{c}\text { Min - Max } \\
\text { average }\end{array}$} \\
\hline & \multicolumn{4}{|c|}{ Roszków reservoir (22 years) } \\
\hline $\mathrm{BOD}_{5}$ & $\begin{array}{l}2-9 \\
5.17\end{array}$ & $\begin{array}{l}2-6 \\
4.33\end{array}$ & $\begin{array}{c}1-7 \\
3.83\end{array}$ & $\begin{array}{c}2-76 \\
16.5\end{array}$ \\
\hline total suspended solids & $\begin{array}{c}31.8-84.8 \\
56.8\end{array}$ & $\begin{array}{c}26-95.6 \\
53.56\end{array}$ & $\begin{array}{c}16.8-184.8 \\
64.7\end{array}$ & $\begin{array}{c}25-113.4 \\
55.03\end{array}$ \\
\hline $\mathrm{N}-\mathrm{NH}_{4}$ & $\begin{array}{c}0.14-0.74 \\
0.41\end{array}$ & $\begin{array}{c}0.12-0.84 \\
0.43\end{array}$ & $\begin{array}{c}0.1-0.69 \\
0.29\end{array}$ & $\begin{array}{c}0.31-12 \\
3.5 \\
\end{array}$ \\
\hline $\mathrm{PO}_{4}$ & $\begin{array}{c}1.1-1.5 \\
1.28\end{array}$ & $\begin{array}{c}1.4-3.1 \\
2.13 \\
\end{array}$ & $\begin{array}{c}0.9-2.1 \\
1.45\end{array}$ & $\begin{array}{c}1.5-2.3 \\
1.8\end{array}$ \\
\hline & \multicolumn{4}{|c|}{ Jeżewo reservoir (15 years) } \\
\hline $\mathrm{BOD}_{5}$ & $\begin{array}{l}2-8 \\
4.82\end{array}$ & $\begin{array}{l}2-10 \\
5.33\end{array}$ & $\begin{array}{l}2-9 \\
4.83\end{array}$ & $\begin{array}{l}2-14 \\
5.67\end{array}$ \\
\hline total suspended solids & $\begin{array}{c}13.6-100 \\
50.83\end{array}$ & $\begin{array}{c}14.6-83.4 \\
48.7\end{array}$ & $\begin{array}{c}5.6-70.6 \\
42.2\end{array}$ & $\begin{array}{c}7.6-62.4 \\
34.93\end{array}$ \\
\hline $\mathrm{N}-\mathrm{NH}_{4}$ & $\begin{array}{c}0.11-1.15 \\
0.45\end{array}$ & $\begin{array}{c}0.03-0.91 \\
0.34\end{array}$ & $\begin{array}{c}0.05-0.6 \\
0.25\end{array}$ & $\begin{array}{c}0.09-4.27 \\
1.19\end{array}$ \\
\hline \multirow[t]{2}{*}{$\mathrm{PO}_{4}$} & $\begin{array}{c}1-1.7 \\
1.48\end{array}$ & $\begin{array}{c}1.1-1.9 \\
1.53\end{array}$ & $\begin{array}{c}1-1.6 \\
1.33\end{array}$ & $\begin{array}{c}1.4-2.5 \\
1.95\end{array}$ \\
\hline & \multicolumn{4}{|c|}{ Jaraczewo reservoir (5 years) } \\
\hline $\mathrm{BOD}_{5}$ & $\begin{array}{l}3-7 \\
5.33\end{array}$ & $\begin{array}{l}2-7 \\
4.16\end{array}$ & $\begin{array}{l}1-6 \\
4.16\end{array}$ & $\begin{array}{l}2-8 \\
5.16\end{array}$ \\
\hline total suspended solids & $\begin{array}{c}62-136.4 \\
89.36\end{array}$ & $\begin{array}{c}15.8-144.3 \\
60.28\end{array}$ & $\begin{array}{c}40.4-346 \\
113.16\end{array}$ & $\begin{array}{c}35-168.4 \\
51.76 \\
\end{array}$ \\
\hline $\mathrm{N}-\mathrm{NH}_{4}$ & $\begin{array}{c}0.04-1.34 \\
0.49\end{array}$ & $\begin{array}{c}0.05-1.29 \\
0.43\end{array}$ & $\begin{array}{c}0.01-1.36 \\
0.44\end{array}$ & $\begin{array}{c}0.14-1.02 \\
0.48\end{array}$ \\
\hline $\mathrm{PO}_{4}$ & $\begin{array}{c}1.1-1.6 \\
1.43\end{array}$ & $\begin{array}{c}1.2-1.6 \\
1.32\end{array}$ & $\begin{array}{c}1.2-1.5 \\
1.3\end{array}$ & $\begin{array}{c}1.1-1.5 \\
1.3\end{array}$ \\
\hline
\end{tabular}

as 20 samples, and ammonium nitrogen in single samples collected in December and May.

The Jeżewo reservoir is located in woodland areas. Despite its favourable location, the water quality is not satisfactory. The water quality analysis of the Jeżewo reservoir showed it was below good. In terms of $\mathrm{BOD}_{5}$, the water quality was determined as class I eleven times and only once as class II throughout the entire test period. In terms of total suspended solids water class I and II were found only three times during the sixmonth research period. In the course of the laboratory analyses carried out in December 2018 and from March to May 2019, all samples exceeded the permissible content of phosphate (V) for water class II, while the content of ammonium nitrogen was exceeded three times.

The Jaraczewo reservoir has the shortest operating time among the analysed reservoirs. However, the water quality in this reservoir is also not satisfactory. During the laboratory analyses, it was observed that the limit values of permissible indicators for water quality class II were substantially exceeded. In terms of $\mathrm{BOD}_{5}$, the value was exceeded in 14 out of 24 samples and in terms of total suspended solids - in 23 out of 24 samples. The analyses of the phosphate phosphorus (V) content showed that the permissible values for all tested samples were exceeded for water class II, while for ammonium nitrogen it was noted that the values were exceeded in 4 samples.

The laboratory analyses also included the tests on total suspended solids. Suspended solids are one of the factors which shape the conditions of biological life in flowing waters, by transporting the substances necessary for the proper functioning of entire food chains over considerable distances. The suspended solids of natural origin and from the discharge of various types of wastewater affect the ecosystem adversely (Anh et al., 1999) i.e. by reducing the reservoir capacity through depositing matter. In addition, suspended solids can transport other types of contaminants, such as heavy metals, especially during periods of high water (Bibby and Webster-Brown, 2005). The concentrations of suspended solids in water for 
dam reservoirs do not exceed $20 \mathrm{mg} \cdot \mathrm{dm}^{-3}$, and the highest concentration occurs in high floods and quite often exceeds the value of $1000 \mathrm{mg} \cdot \mathrm{dm}^{-3}$ (Nocoń, 2012).

On the basis of Figure 2, it can be seen that in all analysed reservoirs the amount of total suspended solids at their outflow exceeds the maximum permissible value $17.3 \mathrm{mg} \cdot \mathrm{dm}^{-3}$. Therefore, in all analysed reservoirs, the water quality can be defined based on this parameter as water class III - V. During the December sampling from the Roszków and Jaraczewo reservoirs, an increase in total suspended solids was observed, the concentration of which then decreased. The same (decreasing) tendency could be seen in the Jeżewo reservoir from December to April.

By analysing the obtained results of $\mathrm{BOD}_{5}$ values and by taking into account the sampling points for all reservoirs (Fig. 3) it is perceivable that the average value is in the range of
4-6 $\mathrm{mg} \cdot \mathrm{dm}^{-3}$. The highest variation in values was observed for the Jeżewo reservoir for the point at the water outflow from the reservoir.

Fig. 4 shows the marked nitrate level taking into account sampling points for all analysed reservoirs. The highest nitrate values were recorded for the Jeżewo reservoir at the inflow to the reservoir. Other results have similar values ranging from 0.25 to $1 \mathrm{mg} \cdot \mathrm{dm}^{-3}$.

According to (Sullivan and Drever, 2001) and (Clark et al., 2004), the changes in the concentration of nutrients, in particular nitrates, are associated with seasonality. A decrease in the biogenic content in spring and summer may be due to the increased decomposition of organic matter in the aquatic environment.

The highest variability in the content of phosphate phosphorus was recorded for the Roszków and Jeżewo reservoirs at their water inflows (Fig. 5). Significantly lower $\mathrm{PO}_{4}$ concentrations

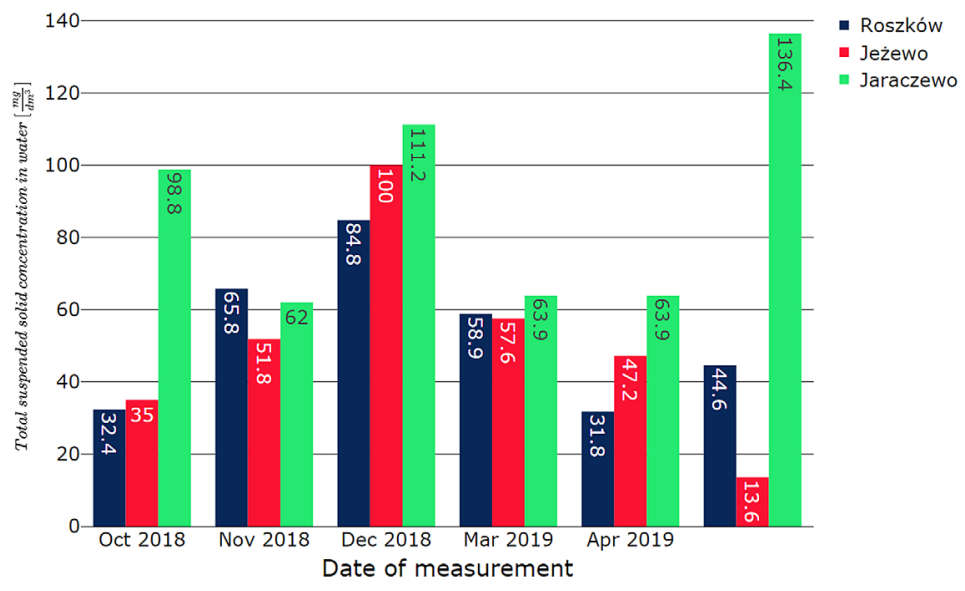

Fig. 2. The content of total suspended solids at the outflow from the reservoirs depending on sampling time

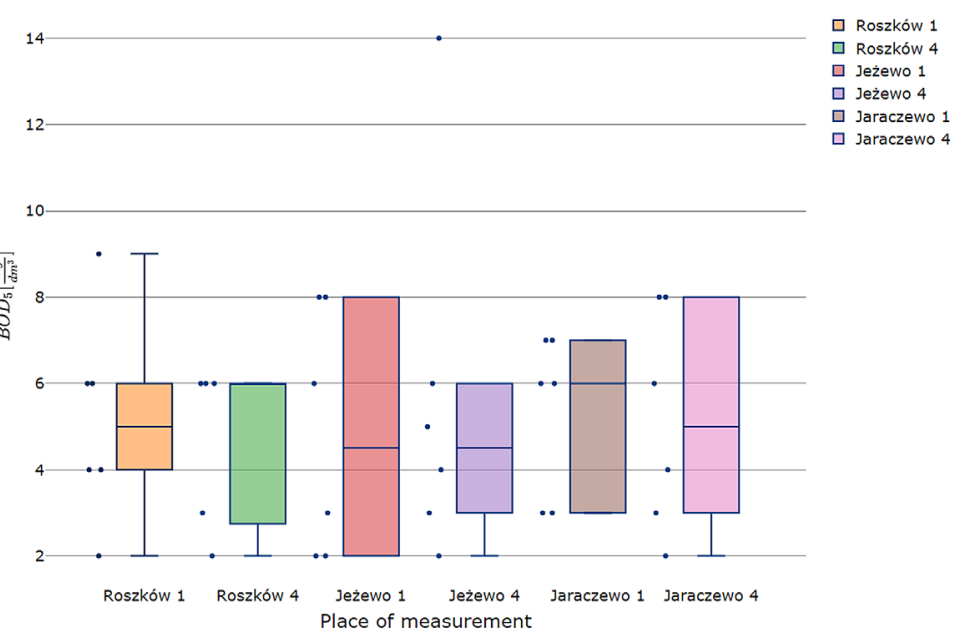

Fig. 3. The value of $\mathrm{BOD}_{5}$ indicator for individual reservoirs depending on sampling points 


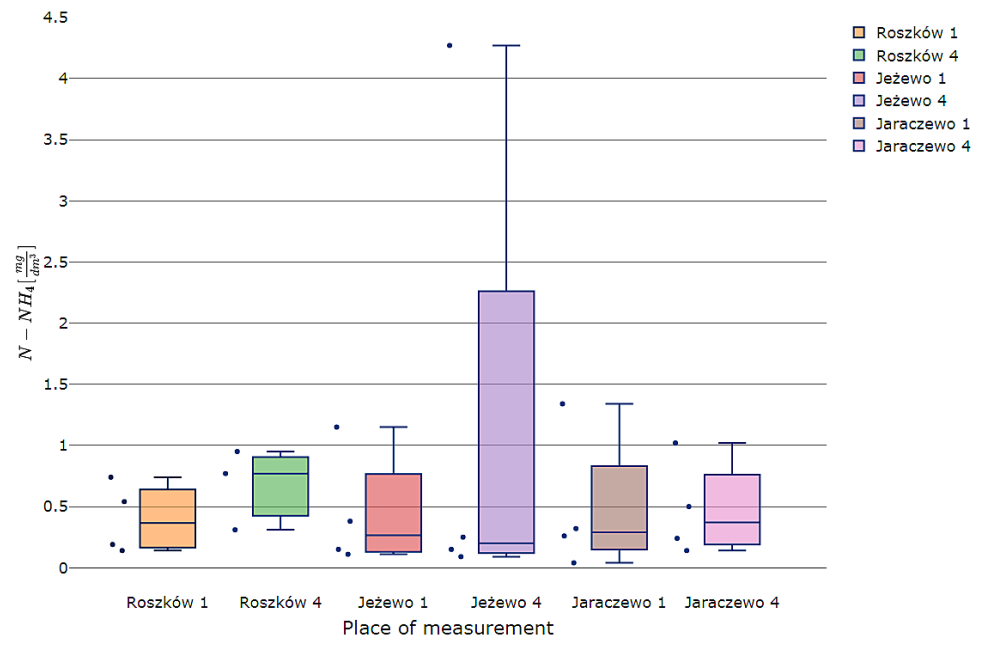

Fig. 4. The N-NH $\mathrm{N}_{4}$ indicator for individual reservoirs depending on sampling points

could also be observed at the outlets from the Roszków and Jeżewo reservoirs, which may suggest that these reservoirs contribute to reducing the concentration of this compound and thus to purifying water from this parameter.

Differences in the phosphorus concentrations may also occur depending on the season of the year. Igras and Jadczyszyn (2008) noticed that higher $\mathrm{PO}_{4}$ concentrations occur in autumn, whereas (Jaskuła et al., 2015) stated that a decrease in the phosphorus concentration noticeable from January to April might be due to dilution of wastewater in the period of more intensive flows.

According to (Pawełek and Grenda, 2011), when water is retained in reservoirs for certain time, it leads to a change in its physical, chemical and biological characteristics. The change in these characteristics can be affected by numerous factors, among others: water retention time in a given reservoir, seasonality and weather conditions, reservoir depth, method of reservoir operation and water flow through a given reservoir providing its good mixing and complete exchange.

A major and frequent problem in lowland river catchment areas is the pollution from agricultural sources, as well as insufficient sanitation of rural and recreational areas (Kanclerz et al., 2014) manifesting as a direct discharge of sewage and pollution into the reservoir. The agricultural areas with an increased load of biogenic compounds and an increase in their concentrations in the inflowing waters (watercourses, surface runoffs, groundwater) often have a significant impact on the condition of biological and physical-chemical elements of reservoirs, which may prevent the good ecological status of their waters (Directive... 2000).

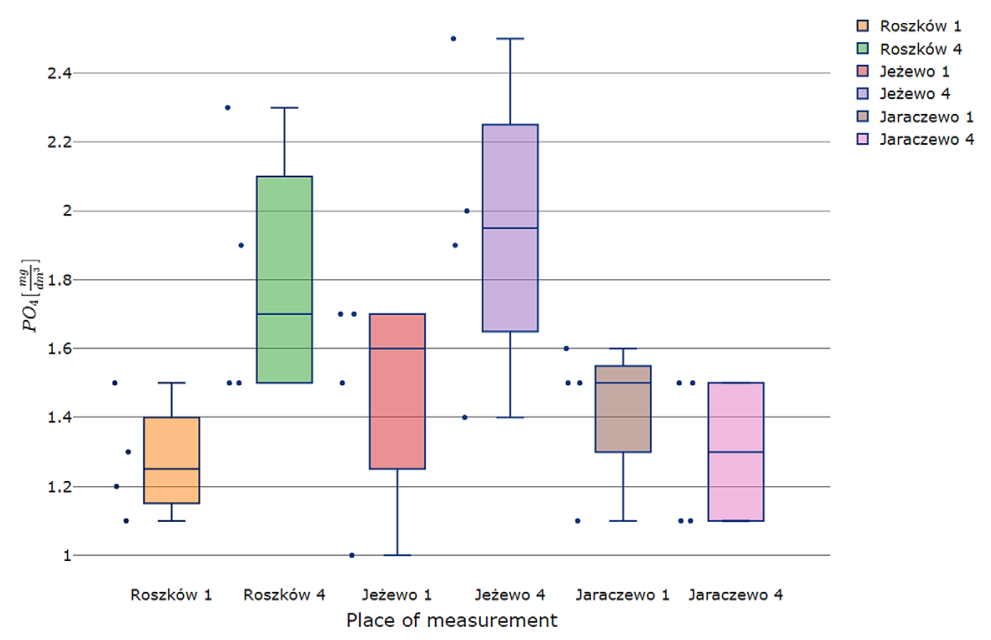

Fig. 5. The $\mathrm{PO}_{4}$ indicator for individual reservoirs depending on sampling points 


\section{CONCLUSIONS}

The following conclusions can be drawn on the basis of the study:

1. Pursuant to the ordinance in force, the water quality in all reservoirs exceeded the 2nd quality class. Therefore, the legislator did not provide any limit values for the remaining classes.

2. The concentrations of $\mathrm{PO}_{4}$ phosphate in all analysed reservoirs correspond to water quality class III-V. Only the Jeżewo reservoir, in terms of $\mathrm{NH}_{4}$ ammonia concentration, can be classified, due to better parameters (15 years of operation), to a higher water quality class; however, according to other parameters, the reservoir remains in class III-V.

3. It was also observed that the water flowing into the Roszków and Jeżewo reservoirs (two oldest reservoirs) was of worse quality than the outgoing water. In these reservoirs, the outflowing water quality parameters were improving compared to those at the inflow; however, the improvement in quality was not found significant enough to classify the water into a higher class.

4. In the case of the newest reservoir, the water quality at the outflow deteriorated in relation to all indicators. It can be concluded that the reasons for this are shorter operating time and improper renaturization procedures.

\section{REFERENCES}

1. Anh, M.T., Triet, L.M., Sauvain, J.-J., Tarradellas, J., 1999. PAH contamination levels in air particles and sediments of Ho Chi Minh City, Vietnam. Bulletin of environmental contamination and toxicology, 63, 728-735.

2. Bayram, A., Önsoy, H., Kömürcü, M.İ., Tüfekçi, M., 2014. Reciprocal influence of Kürtün Dam and wastewaters from the settlements on water quality in the stream Harşit, NE Turkey. Environmental earth sciences, 72, 2849-2860.

3. Bibby, R.L., Webster-Brown, J.G., 2005. Characterisation of urban catchment suspended particulate matter (Auckland region, New Zealand); a comparison with non-urban SPM. Science of the Total Environment, 343, 177-197.

4. Bieroński, J., 2014. Small retention ponds and reservoirs - the problems of functioning. In Polish. Problemy Ekologii Krajobrazu, 17.

5. Budkowska Katarzyna, 2019. Assessment of the quality of selected water reservoirs in the Greater Poland Voivodeship. The manuscript thesis. In
Polish. UPP Poznań, Poznań.

6. Clark, M.J., Cresser, M.S., Smart, R., Chapman, P.J., Edwards, A.C., 2004. The influence of catchment characteristics on the seasonality of carbon and nitrogen species concentrations in upland rivers of Northern Scotland. Biogeochemistry, 68, 1-19.

7. Czerniak, A., Pelc, Z., 2006. Identification of effects after the retention tank "Jeżewo" is built in Piaski Forest District. Inżynieria i Kształtowanie Środowiska, 71.

8. Friedl, G., Wüest, A., 2002. Disrupting biogeochemical cycles-Consequences of damming. Aquatic Sciences, 64, 55-65.

9. Fučík, P., Kvítek, T., Lexa, M., Novák, P., Bílková, A., 2008. Assessing the stream water quality dynamics in connection with land use in agricultural catchments of different scales. Soil and Water Research, 3, 98-112.

10. Gallo, E.L., Meixner, T., Aoubid, H., Lohse, K.A., Brooks, P.D., 2015. Combined impact of catchment size, land cover, and precipitation on streamflow and total dissolved nitrogen: A global comparative analysis. Global Biogeochemical Cycles, 29, 1109-1121.

11. Giercuszkiewicz-Bajtlik, M., 1990. Forecasting changes in the quality of stagnant waters. In Polish. Dział Wydawnictw Instytutu Ochrony Środowiska.

12. Grizzetti, B., Passy, P., Billen, G., Bouraoui, F., Garnier, J., Lassaletta, L., 2015. The role of water nitrogen retention in integrated nutrient management: assessment in a large basin using different modelling approaches. Environmental Research Letters, 10, 65008.

13. Grochowska, J., Karpienia, M., Tandyrak, R., Płachta, A., Dziczek, J., Gołębiewska, A.E., Jędrzejewski, P., Tomczak, M., Turek, M., Zaręba, F., 2019. Preliminary characteristic of water chemistry of lake Bartąg near Olsztyn and sketch of its protection concept. In Polish. Woda-ŚrodowiskoObszary Wiejskie, 19, 5-18.

14. Gromiec, M., Dojlido, J., 2006. Water quality changes in selected water reservoirs. In Polish. IMiGW, Warszawa.

15. Igras, J., Jadczyszyn, T., 2008. Content of nitrates and phosphates in shallow groundwater in Poland. In Polish. Problemy inżynierii rolniczej, 16, 91-102.

16. Ilnicki, P., 2002. Causes, sources and course of surface waters eutrophication. In Polish. Przegląd komunalny, 35-49.

17. Jaskuła, J., Sojka, M., Wicher-Dysarz, J., 2015. Analysis of trends changes in physicochemical state of the Główna river. In Polish. Inżynieria Ekologiczna, 154--161.

18. Juszczak, R., Kędziora, A., 2004. Water retention of small ponds in the western part of the Wyskoć 
catchment. Roczniki AR Poznań, 25, 193-200.

19. Kanclerz, J., Murat-Blazejewska, S., Sojka, M., Przybyl, A., 2010. Changes of the water quality and the fish structure in the lowland river in the year 2000-2009. In Polish. Infrastruktura i Ekologia Terenów Wiejskich.

20. Kanclerz, J., Wicher-Dysarz, J., Dysarz, T., Sojka, M., Dwornikowska, Ż., 2014. Influence of the Stare Miasto reservoir on the Powa river water quality. In Polish. Nauka Przyroda Technologie, 8, p. 54.

21. Kowalik, T., Kanownik, W., Bogdał, A., Policht-Latawiec, A., 2014. The effect of the change in upland catchment use on forming surface water quality. In Polish. Rocznik Ochrona Środowiska (Annual Set The Environment Protection), 16, 223-238.

22. Malek, S., Jasik, M., Durlo, G., 2019. Quality of water from the intakes located in the forest areas manager by the Myślenice Forest District. In Polish. Sylwan, 163.

23. Mioduszewski, W., 2008. Small retention in forests as an element of improving and protection of water resources. In Polish. Studia i Materiały Centrum Edukacji Przyrodniczo-Leśnej, 10, 33-48.

24. Morawiec, A., Organ, A., Piec, L., Czop, M., Kajda-Szcześniak, M., 2019. Basic physicochemical properties of selected waters depending on their role in the environment. In Polish, Contemporary Problems of Environmental Protection and Energy 2018. Katedra Technologiii Urządzeń Zagospodarowania Odpadów, Gliwice, 199-209.

25. Nocoń, W., 2012. Suspension in the flowing waters of the Upper Silesian agglomeration - problems and challenges. In Polish. LAB Laboratoria, Aparatura, Badania, 17, 39-43.

26. Orzepowski, W., Paruch, A.M., Pulikowski, K., Kowalczyk, T., Pokładek, R., 2014. Quantitative and qualitative assessment of agricultural water resources under variable climatic conditions of Silesian Lowlands (Southwest Poland). Agricultural Water Management, 138, 45-54.

27. Pawełek, J., Grenda, W., 2011. Effect of the Storage
Reser-voirs at the Rudawa River Intake on the Quality of the Municipal Water for Krakow. In Polish. Ochrona Środowiska, 33, 63-66.

28. Policht-Latawiec, A., Bogdał, A., Kanownik, W., Kowalik, T., Ostrowski, K., Gryboś, P., 2014. Quality and usable values of small flysch river water. In Polish. Rocznik Ochrona Środowiska, 16, 546-561.

29. Pulikowski, K., Czyzyk, F., Paweska, K., Strzelczyk, M., 2012. Participation of nitrate nitrogen in total nitrogen content in waters outflowing from catchment with agricultural use. In Polish. Infrastruktura i Ekologia Terenów Wiejskich.

30. Smoroń, S., Twardy, S., 2004. Loads of mineral nutrients to the upper Dunajec catchment area over two decades (1976-1996). In Polish. Woda-ŚrodowiskoObszary Wiejskie, 4, 147-158.

31. Sojka, M., 2009. Assessment of biogenic compounds eluted from the catchment of Dębina river. In Polish. Środkowo-Pomorskie Towarzystwo Naukowe Ochrony Środowiska, 11, 1225-1234.

32. Sullivan, A.B., Drever, J.I., 2001. Spatiotemporal variability in stream chemistry in a high-elevation catchment affected by mine drainage. Journal of Hydrology, 252, 237-250.

33. Szczykowska, J., Siemieniuk, A., 2011. Importance of retention reservoirs in rural areas and their waters' quality. In Polish. Inżynieria Ekologiczna, 103-111.

34. Wiatkowski, M., Paul, L., 2009. Surface Water Quality Assessment in the Troja River Catchment in the Context of Włodzienin Reservoir Construction. Polish Journal of Environmental Studies, 18.

35. Wiatkowski, M., Rosik-Dulewska, C., Opolski, U., 2016. Hydrological and hydraulic conditions for a construction of a pre-dam reservoir in the Słup reservoir backwater. In Polish. Rocznik Ochrona Środowiska, 18, 468--479.

36. Wilk, P., Orlińska-Woźniak, P., Szalińska, E., 2019. Assessment of total nitrogen loads discharged from agricultural catchments in the context of changes in the nitrates directive implementation. In Polish. Ochrona Środowiska, 41, 55-64. 